Available online http://iurnalmahasiswa.uma.ac.id/index.php/arbiter

\title{
Analisis Hukum Terhadap Pertanggungjawaban Pelaku Pidana Penggelapan (Studi Kasus Pada Pengadilan Negeri Lubuk Pakam)
}

\section{Legal Analysis of the Liability of Criminal Offenders (Case Study at the Lubuk Pakam District Court) \\ Bisker Manik' ${ }^{1}$, Mahmud Mulyadi'2) \& Muazzul 3)*}

\author{
Program Pasca Sarjana, Magister Ilmu Hukum, Universitas Medan Area, Indonesia \\ Fakultas Hukum Universitas Sumatera Utara, Indonesia \\ Fakultas Hukum Universitas Medan Area, Indonesia
}

\begin{abstract}
Abstrak
Penelitian ini bertujuan untuk melihat secara kriminologis dan yuridis tentang kejahatan dalam tindakan manusia yang mengkompromikan norma dasar masyarakat. Perbuatan elemen yang melanggar aturan yang hidup dan berkembang di masyarakat. Jenis penelitian yang digunakan adalah deskriptif analitis tentang normatif yuridis, bahan utama dalam penelitian ini adalah data sekunder yang dilakukan dengan menghimpun bahan-bahan berupa : Bahan Hukum Primer, yaitu bahan hukum berupa peraturan perundang-undangan, dokumen resmi yang mempunyai otoritas yang berkaitan dengan permasalahan, yaitu KUHP. Bahan Hukum Sekunder, yaitu semua bahan hukum yang merupakan publikasi dokumen tidak resmi meliputi buku-buku, karya ilmiah. Bahan Hukum Tertier, yaitu bahan yang memberikan maupun penjelasan terhadap bahan hukum primer dan bahan hukum sekunder, seperti kamus umum, kamus hukum, jurnal ilmiah, majalah, surat kabar dan internet yang masih relevan dengan penelitian ini, Hasil penelitian dan diskusi untuk menjelaskan unsur-unsur kejahatan penggelapan terdiri dari unsur-unsur pelanggaran Subyektif dalam bentuk pelanggar yang disengaja untuk menggelapkan harta orang lain sebagaimana didefinisikan dalam pasal undang-undang melalui kata-kata: sengaja dan unsur pelanggaran Oyektif terdiri dari: elemen siapa pun, elemen menguasai secara tidak sah, elemen objek, elemen sebagian atau seluruhnya dimiliki oleh orang lain dan elemen objek di sana bukan untuk kejahatan.

Kata Kunci: pelaku pidana, penggelapan, pengadilan negeri
\end{abstract}

\begin{abstract}
This study aims to look criminologically and juridically about crime in human actions that compromises the basic norms of society. Actions of elements that break the rules that live and develop in society. This type of research is analytical descriptive of juridical normative, the main material in this research is secondary data which is done by collecting material in the form of: Primary Legal Material, namely legal material in the form of laws and regulations, official documents that have authority related to the problem, namely the Criminal Code. Secondary Legal Material, which is all legal material which is an unofficial document publication including books, scientific works. Tertiary Legal Materials, i.e. materials that provide and explain primary and secondary legal materials, such as public dictionaries, legal dictionaries, scientific journals, magazines, newspapers and the internet that are still relevant to this research, research results and discussions to explain the elements the element of embezzlement consists of elements of subjective offense in the form of a deliberate offender to embezzle the assets of others as defined in the article of the law through the words: intentionally and the element of Oyective violation consists of: anyone's element, element of illegally controlling, object elements, elements partially or wholly owned by others and the object elements there are not for crime.
\end{abstract}

Keywords: criminal, embezzlement, district court

How to Cite: Bisker Manik, Mahmud Mulyadi \& Muazzul (2019). Analisis Hukum Terhadap Pertanggungjawaban Pelaku Pidana Penggelapan (Studi Kasus Pada Pengadilan Negeri Lubuk Pakam). ARBITER: Jurnal Ilmiah Magister Hukum, 1(1): 68-77,

*E-mail: Manik.bisker@yahoo.co.id ISSN 2550-1305 (Online)

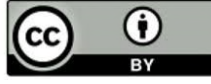

This work is licensed under a Creative Commons Attribution 4.0 


\section{PENDAHULUAN}

Penggelapan adalah kejahatan yang hampir sama dengan pencurian yang dijelaskan dalam Pasal 362. Pada pencurian barang yang dimiliki itu masih belum berada di tangan pelaku dan masih harus diambilnya, sedang pada penggelapan waktu dimilikinya barang itu sudah ada di tangan pelaku tidak dengan jalan kejahatan.

Menurut KUHP tindak pidana penggelapan dibedakan atas lima macam, yaitu: Pertama, tindak pidana penggelapan dalam bentuk pokok; Kedua, tindak pidana penggelapan ringan; Ketiga, tindak pidana penggelapan dengan unsur-unsur yang memberatkan; Keempat, tindak pidana penggelapan oleh wali dan lain-lain; Kelima, tindak pidana penggelapan dalam keluarga.

Unsur-unsur yang terdapat dalam Pasal 372 KUHPidana ini terdiri dari unsur objektif dan subjektif:Unsur subjektif yakni Unsur kesengajaan; memuat pengertian mengetahui dan menghendaki. Berbeda dengan tindak pidana pencurian yang tidak mencantumkan unsur kesengajaan atau „opzettelijk“ sebagai salah satu unsur tindak pidana pencurian. Rumusan Pasal 372 KUHPidana mencantumkan unsur kesengajaan pada tindak pidana Penggelapan, sehingga dengan mudah orang mengatakan bahwa penggelapan merupakan opzettelijk delict atau delik sengaja.

Sementara unsur objektif terdiri dari: Pertama, Barang siapa; seperti yang telah dipaparkan dalam tindak pidana pencurian, kata „barang siapa“ ini menunjukan orang. Seseorang telah memenuhi semua unsur tindak pidana penggelapan maka dia dapat disebut pelaku atau „dader'. Kedua, Menguasai secara melawan hukum (bermaksud memiliki); mentri kehakiman pemerintahan kerajaan Belanda, menjelaskan maksud unsur ini adalah penguasaan secara sepihak oleh pemegang sebuah benda seolah-olah merupakan pemiliknya, bertentangan dengan hak yang membuat benda tersebut berada padanya. Ketiga, Suatu benda; ialah benda yang menurut sifatnya dapat dipindahpindahkan ataupun dalam prakteknya sering disebut „benda bergerak“. Keempat, Seluruh atau sebagiannya adalah milik orang lain. Kelima, Benda yang ada dalam kekuasaannya tidak karena kejahatan; yaitu harus ada hubungan langsung yang sifatnya nyata antara pelaku dengan suatu benda pada tindak pidana penggelapan.

Penggelapan dalam rumusan KUHP adalah tindak kejahatan yang meliputi unsurunsur: Dengan sengaja; Barang siapa; Mengambil; Suatu benda; Sebagian/seluruhnya kepunyaan orang lain; Menguasai benda tersebut dengan melawan hukum; dan Benda Yang ada dalam kekuasaannya tidak karena kejahatan.

Menurut Cleiren inti delik penggelapan ialah penyalahgunaan kepercayaan. Selalu menyangkut secara melawan hukum memiliki suatu barang yang dipercayakan kepada orang yang menggelapakan itu. Batas klasik antara pencurian dan penggelapan ialah pencurian "mengambil" barang yang belum ada padanya, sedangkan pada penggelapan barang itu sudah ada di dalam kekuasaannya. Delik penggelapan adalah delik dengan berbuat atau delik komisi. Waktu dan tempat terjadinya penggelapan ialah waktu dan tempat dilaksanakannya kehendak yang sudah nyata.

Bentuk pokok pembentuk undang-undang telah mencantumkan unsur kesengajaan atau opzettelijk sebagai salah satu unsur dalam tindak pidana penggelapan. Unsur dengan sengaja merupakan satu-satunya unsur subjektif didalam tindak pidana penggelapan, 
yakni unsur yang melekat pada subjek tindak pidana ataupun yang melekat pada pribadi pelakunya. Unsur opzettelijk harus didakwakan didalam surat dakwaan, dan karena unsur tersebut didakwaan terhadap seorang terdakwa, dengan sendirinya juga harus dibuktikan di sidang pengadilan yang memeriksa perkara terdakwa.

Tiap kejahatan yang diatur dalam KUHP maupun diatur dalam peraturan perundangundangan yang lain mempunyai unsur-unsur yang harus dipenuhi sesuai dengan yang dilakukan. (Taufik S, dkk 2008), Untuk dapat mengemukakan unsur-unsur kejahatan penggelapan, maka harus terpenuhi unsur-unsur sebagai berikut: Pertama, yang bersalah harus bermaksud memiliki benda itu, Kedua, benda itu harus kepunyaan orang lain, baik seluruhnya atau sebahagian, Ketiga, benda itu harus sudah ada di tangan yang melakukan perbuatan itu, bukan memiliki benda itu harus tanpa hak.

Dalam menerapkan hukum dan menjalankan peradilan, hakim memiliki peranan yang sangat penting. Dalam memeriksa dan mengadili suatu perkara banyak hal yang menjadi pertimbangan hakim untuk dapat menghasilkan putusan yang seadil-adilnya, baik bagi korban, terdakwa, maupun masyarakat umum. Alasan dan pertimbangan yang digunakan oleh hakim sangat kompleks supaya dalam mengadili dan menghasilkan sebuah putusan dalam menjatuhkan sanksi kepada terdakwa agar menghasilkan putusan yang dapat diterima bagi terdakwa serta masyarakat dan sesuai dengan tujuan hukum yaitu keadilan, kemanfaatan, dan kepastian hukum. Penulis ingin mengetahui faktorfaktor yang dijadikan dasar pertimbangan hakim dalam memeriksa dan memutus perkara. Penulis juga ingin mengetahui sanksi pidana yang dijatuhkan oleh hakim terhadap aturan hukum acara pidana yang berlaku.

\section{METODE PENELITIAN}

Sesuai dengan permasalahan dan tujuan penelitian ini, maka jenis penelitian yang digunakan adalah deskriptif analitis, maksudnya adalah suatu analisis data yang berdasarkan pada teori hukum yang bersifat umum diaplikasikan untuk menjelaskan tentang seperangkat data yang lain (Sunggono, 1997). Jenis penelitian yang diterapkan adalah memakai penelitian dengan metode penulisan dengan pendekatan yuridis normatif (penelitian hukum normatif), yaitu penelitian yang mengacu kepada normanorma hukum yang terdapat dalam peraturan perundang-undangan yang berlaku sebagai pijakan normatif.

Bahan utama dalam penelitian ini adalah data sekunder yang dilakukan dengan menghimpun bahan-bahan berupa : Bahan Hukum Primer, yaitu bahan hukum berupa peraturan perundang-undangan, dokumen resmi yang mempunyai otoritas yang berkaitan dengan permasalahan, yaitu KUHP. Bahan Hukum Sekunder, yaitu semua bahan hukum yang merupakan publikasi dokumen tidak resmi meliputi buku-buku, karya ilmiah. Bahan Hukum Tertier, yaitu bahan yang memberikan maupun penjelasan terhadap bahan hukum primer dan bahan hukum sekunder, seperti kamus umum, kamus hukum, jurnal ilmiah, majalah, surat kabar dan internet yang masih relevan dengan penelitian ini. 


\section{HASIL DAN PEMBAHASAN}

\section{Unsur-Unsur Tindak Pidana Penggelapan}

Dalam ketentuan Pasal 374 KUHP terdapat unsur-unsur objektif, yang meliputi; Perbuatan memiliki, Zicht toe. igenen menganggap sebagai milik atau ada kalanya menguasai secara melawan hak atau mengaku sebagai milik, dengan kata lain memiliki adalah setiap perbuatan penguasaan atas benda atau lebih tegas pada setiap tindakan yang mewujudkan suatu kehendak untuk melakukan kekuasaan yang nyata dan mutlak atas benda itu, hingga tindakan itu merupakan perbuatan sebagai pemilik atas benda itu. Mahkamah Agung dalam putusannya tanggal 25 Februari 1958 No. 308 K/Kr/1957 menyatakan bahwa perkataan Zicht toe. Igenen dalam bahasan Indonesia belum ada terjemahan resmi sehingga kata-kata itu dapat diterjemahkan dengan perkataan mengambil atau memiliki. Pada penggelapan memiliki unsur objektif, yakni unsur tingkah laku atau perbuatan yang dilarang dalam penggelapan, maka memiliki itu harus ada bentuk dan wujudnya, bentuk mana harus sudah selesai dilaksanakan sebagai syarat untuk menjadi selesainya penggelapan. Perbuatan memiliki adalah aktif, jadi harus ada wujud konkretnya. Pada kenyataannya wujud perbuatan memiliki empat kemungkinan, yaitu: Perbuatan yang wujudnya berupa mengalihakn kekuasaan atas benda objek penggelapan atau dengan kata lain perbuatan yang mengakibatkan beralihnya kekuasaan atas benda ke dalam kekuasaan orang lain, selesainya perbuatan ini apabila kekuasaan atas benda telah beralih ke dalam kekuasaan orang lain atau sudah lepas dari kekuasaan pembuat; Perbuatan tidak mengakibatkan beralihnya kekuasaan atas benda objek kejahatan, akan tetapi mengakibatkan benda menjadi lenyap (bukan hilang) atau habis; Perbuatan memiliki atas benda yang berakibat benda itu berubah bentuknya atau menjadi benda lain; Perbuatan memiliki yang tidak menimbulkan akibat beralihnya kekuasaan atas benda dan juga benda tidak lenyap atau habis atau berubah bentuk melainkan benda digunakan dengan melawan hak.

Unsur objek kejahatan: suatu benda. Pengertian yang berada dalam kekuasaannya sebagai adanya suatu hubungan langsung dan sangat erat dengan benda itu yang sebagai indikatornya adalah apabila ia hendak melakukan perbuatan terhadap benda itu, dia dapat melakukannya secara langsung tanpa harus melakukan perbuatan lain terlebih dahulu adalah hanya terhadap benda-benda berwujud dan bergerak saja dan tidak mungkin terjadi pada benda-benda yang tidak berwujud dan benda-benda tetap; a). Benda di bawah kekuasaan si pelaku .Unsur ini adalah unsur pokok dari penggelapan benda yang membedakan dari tindak pidana lain dari kekayaan orang lain; b). Benda milik orang lain. Unsur ini adalah unsur yang menimbulkan kesulitan dalam hal jumlah uang tunai yang dipercayakan oleh empunya kepada orang lain untuk disimpan atau untuk dipergunakan melakukan pembayaran tertentu;c). Unsur objek kejahatan: suatu benda Benda yang tidak ada pemiliknya baik sejak semula maupun telah dilepaskan hak miliknya tidak dapat menjadi objek penggelapan. Benda milik suatu badan hukum, seperti milik negara adalah berupa benda yang tidak atau dimiliki orang orang adalah ditafsirkan sebagai milik orang lain dalam arti bukan milik pelaku atau oleh karena itu dapat menjadi objek penggelapan. Arrest HR tanggal 1 Mei 1992 dengan tegas menyatakan bahwa untuk menghukum karena penggelapan tidak diisyaratkan bahwa menurut hukum terbukti siapa pemilik benda itu, 
sudah cukup terbukti penggelapan bila seseorang menemukan sebuah arloji di kamar mandi di stasiun kereta api, diambilnya dan kemudian timbul niatnya untuk menjualnya, lalu menjualnya; d). Benda berada dalam kekuasaan bukan karena kejahatan. Ciri khusus tindak pidana penggelapan ini adalah terletak pada unsur beradanya benda dalam kekuasan pelaku, suatu benda milik orang lain berada dalam kekuasaan seseorang dapat oleh sebab perbuatan melawan hukum maupun oleh sebab perbuatan yang sesuai dengan hukum, sedangkan yang menjadi syarat dalam penggelapan ini adalah bahwa benda tersebut berada dalam kekuasaan pelaku itu haruslah oleh sebab perbuatan yang sesuai dengan hukum seperti karena penitipan, pinjaman, perjanjian sewa, penggadaian, dan lain sebagainya (A. Hakim, Tan Kamello, 2013).

Unsur subjektif; Unsur Kesengajaan. Unsur ini adalah merupakan unsur kesalahan dalam penggelapan, kesalahan (schuld) terdiri dari dua bentuk yakni kesengajaan (opzettelijk atau dolus) dan kelalaian. Apabila diterangkan lebih lanjut kesengajaan pelaku dalam penggelapan berarti:1). Pelaku mengetahui sadar bahwa perbuatan memiliki benda orang lain yang berada dalam kekuasaannya itu sebagaiperbuatan melawan hukum, suatu perbuatan hukum, suatu perbuatan yang bertentangan dengan kewajiban hukumnya atau bertentangan dengan hak orang lain/ pelaku dengan kesadarannya yang demikian itu menghendaki untuk melakukan perbuatan memiliki; 2). Pelaku mengetahui menyadari bahwa ia melakukan perbuatan memiliki itu adalah terhadap suatu benda yang juga disadarinya bahwa benda itu adalah milik orang lain sebahagian atau seluruhnya; 3). Pelaku mengetahui, menyadari bahwa benda milik orang lain itu berada dalam kekuasaannya bukan karena kejahatan.

Unsur Kesengajaan. Bersifat melawan hukum mutlak untuk setiap tindak pidana. Roeslan Saleh mengatakan, "memidana sesuatu yang tidak bersifat melawan hukum tidak ada artinya". Salah satu unsur esensial delik adalah sifat melawan hukum dinyatakan dengan tegas atau tidak di dalam suatu pasal undang-undang pidana, karena alangkah janggalnya kalau seseorang dipidana yang melakukan perbuatan yang tidak melawan hukum (E. Nasution, E. 2015). Dengan demikian, untuk dapat dikatakan seesorang melakukan tindak pidana, perbuatannya tersebut harus bersifat melawan hukum. Suatu perbuatan baru dapat dikatakan tindak pidana, jika perbuatan itu juga bersifat melawan hukum. Bukan berarti tindak pidana yang tidak memuat perkataan "melawan hukum" tidak dapat bersifat melawan hukum. Sifat melawan hukumnya akan tersimpul dari unsur tindak pidana lain. Dengan demikian melawan hukum dibuktikan sepanjang menjadi rumusan tindak pidana. Hal tersebut juga berdampak pada bunyi putusan.

\section{Pertanggungjawaban Pelaku Tindak Pidana Penggelapan Dalam Wilayah Pengadilan Negeri Lubuk Pakam}

Adanya unsur kesengajaan atau kelalaian merupakan salah satu syarat untuk dapat dipertanggungjawabnya pembuat delik. Perlu diingat bahwa sebagaian besar penulis hukum pidana menagatakan bahwa sengaja itu suatu pengertian yang tidak berwarna, artinya tidak perlu pembuat mengetahui bahwa perbuatannya itu dilarang oleh undangundang. Mengenai kelalaian undang-undang tidak memberi defenisi apakah kelalaian itu, hanya memori penjelasan (memorie van Teolichting) mengatakan, bahwa kelalaian (culpa) 
terletak antara sengaja dan kebetulan. bagaimana pun juga culpa itu dipandang lebih ringan dibanding dengan sengaja (Soesilo, 2001).

Tidak adanya alasan peniadaan pidana merupakan syarat untuk dapat dipertanggungjawabkannya pembuat delik. jika terdapat alasan terhadap peniadaan pidana maka pembuat delik tidak dapat dipertanggungjawabkan atas perbuatannya. Adapun yang merupakan alasan peniadaan pidana, yaitu sebagai berikut:a.Keadaan darurat (Pasal 48 KUHP); b. Pembelaan terpaksa (Pasal 49 ayat 1 KUHP); c. Menjalankan peraturan perundang-undangan (Pasal 50 KUHP); d. Menjalankan perintah jabatan yang sah (Pasal 51 ayat 1 KUHP); e. Tidak mampu bertanggungjawab (Pasal 44 KUHP); f. Daya paksa (Pasal $48 \mathrm{KUHP}$ ); g. Pembelaan terpaksa melampaui batas (Pasal 49 ayat 2 KUHP); h. Menjalankan perintah jabatan yang sah (Pasal 51 ayat 2 KUHP).

Berdasarkan uraian di atas apabila dilihat perbuatan seseorang melakukan penggelapan bukan disebabkan adanya alasan peniadaan pidana tetapi dilakukan secara segaja. Melawan hukum juga merupakan suatu unsur dapat dimintakannya pertanggungjawaban pidana seorang yang melakukan tindak pidana penggelapan sebagaimana diatur dalam KUHP. Melawan hukum itu sendiri banyak pengertiannya. melawan hukum bisa juga diartikan sebagai tanpa hak sendiri (zonder eigen recht), ada juga yang mengartikan bertentangan dengan hak orang lain (tegen eens anders recht), dan juga ada yang mengartikan dengan, bertentangan dengan hukum objektif (tegen het objectieve recht). yang jelas, Melawan hukum merupakan bagian inti (bestanddeel) delik, artinya adalah secara jelas dirumuskan dalam rumusan delik. dalam perjalannya melawan hukum dapat dibagi kedalam: a. Melawan hukum formil yaitu perbuatan yang bertentangan dengan undang-undang; b. Melawan hukum Materiil yaitu perbuatan perbuatan yang tercela dan bertentangan dengan rasa keadilan masyarakat.

Melawan hukum materil dibagi kembali kedalam : a. Melawan hukum dalam fungsi negatif yaitu meski perbuatan memenuhi unsur tindak pidana tetapi tidak bertentangan dengan rasa keadilan masyarakat, maka perbuatan itu tidak dipidana; b. Melawan hukum dalam fungsi positif yaitu meski perbuatan tidak memenuhi unsur tindak pidana, tetapi jika perbuatan itu dianggap tercela karena tidak sesuai rasa keadilan atau norma dalam masyarakat, maka perbuatan itu dapat dipidana

\section{Kendala Dan Upaya Dalam Penegakan Hukum Terhadap Tindak Pidana Penggelapan Di Wilayah Pengadilan Negeri Lubuk Pakam}

Kendala dalam penegakan hukum tindak pidana penggelapan khususnya di lingkungan Pengadilan Negeri Lubuk Pakam. Kendala-kendala tersebut dapat disebutkan: 1. Pola dan bentuk serta modus operandi kejahatan penggelapan semakin berkembang;

Kendala utama penegakan hukum tindak pidana penggelapan adalah pola dan bentuk serta modus operandi kejahatan penggelapan yang semakin berkembang sesuai dengan perkembangan jaman. Keadaan ini memberikan akibat ketidaksesuaian peraturan terkait dalam mengatur tindak pidana penggelapan; Perkembangan teknologi yang semakin maju juga menjadi sarana bagi pihak-pihak yang tidak bertanggungjawab untuk melakukan tindak pidana penggelapan dan tindak pidana lainnya; Sulitnya mencari alat bukti. Hal lainnya yang berhubungan dengan kendala dalam penegakan hukum tindak 
pidana penggelapan adalah sulitnya mencari alat bukti sebagai tindak lanjut pelaksanaan pertanggungjawaban pidana pelaku penggelapan itu sendiri.

Langkah dan strategi yang sangat mendesak (urgent) untuk dilakukan saat ini sebagai solusi terhadap persoalan tersebut ialah melakukan pembenahan dan penataan terhadap sistem hukum yang ada. Sebagai masyarakat Indonesia, negeri ini butuh penegakkan hukum yang adil dan tegas. Tidak ada diskriminasi dalam penegakkanya, masyarakat Indonesia begitu haus dengan penegakkan hukum yang adil.

Pokok penegakan hukum sebenarnya terletak pada faktor-faktor lain yang mungkin mempengaruhinya. Faktor-faktor tersebut mempunyai arti yang netral, sehingga dampak positif atau negatifnya terletak pada isi faktor-faktor tersebut (Soekant, 1986). Faktorfaktor tersebut adalah, sebagai berikut: Faktor hukumnya sendiri, dalam hal ini dibatasi pada undang-undang saja; Faktor penegak hukum, yakni pihak-pihak yang membentuk maupun menerapkan hokum; Faktor sarana atau fasilitas yang mendukung penegakan hokum; Faktor masyarakat, yakni lingkungan dimana hukum tersebut berlaku atau diterapkan; Faktor kebudayaan, yakni sebagai hasil karya, cipta, dan rasa yang didasarkan pada karsa manusia di dalam pergaulan hidup

Kelima faktor tersebut saling berkaitan dengan eratnya, oleh karena merupakan esensi dari penegakan hukum, juga merupakan tolak ukur daripada efektivitas penegakan hukum. Dengan demikian, maka kelima faktor tersebut akan dibahas lebih lanjut dengan mengetengahkan contoh-contoh yang diambil dari kehidupan masyarakat Indonesia.

Penegak hukum merupakan golongan panutan dalam masyarakat, yang hendaknya mempunyai kemampuan-kemampuan tertentu sesuai dengan aspirasi masyarakat. Mereka harus dapat berkomunikasi dan mendapat pengertian dari golongan sasaran, disamping mampu menjalankan atau membawakan peranan yang dapat diterima oleh mereka.

Ada beberapa halangan yang mungkin dijumpai pada penerapan peranan yang seharusnya dari golngan sasaran atau penegak hukum, Halangan-halangan tersebut, adalah: Keterbatasan kemampuan untuk menempatkan diri dalam peranan pihak lain dengan siapa dia berinteraksi; Tingkat aspirasi yang relatif belum tinggi; Kegairahan yang sangat terbatas untuk memikirkan masa depan, sehingga sulit sekali untuk membuat proyeksi; Belum ada kemampuan untuk menunda pemuasan suatu kebutuhan tertentu, terutama kebutuhan material; Kurangnya daya inovatif yang sebenarnya merupakan pasangan konservatisme.

Halangan-halangan tersebut dapat diatasi dengan membiasakan diri dengan sikapsikap, sebagai berikut: Sikap yang terbuka terhadap pengalaman maupun penemuan baru;Senantiasa siap untuk menerima perubahan setelah menilai kekurangan yang ada pada saat itu; Peka terhadap masalah-masalah yang terjadi di sekitarnya; Senantiasa mempunyai informasi yang selengkap mungkin mengenai pendiriannya; Orientasi ke masa kini dan masa depan yang sebenarnya merupakan suatu urutan; Menyadari akan potensi yang ada dalam dirinya; Berpegang pada suatu perencanaan dan tidak pasrah pada nasib; Percaya pada kemampuan ilmu pengetahuan dan teknologi di dalam meningkatkan kesejahteraan umat manusia; Menyadari dan menghormati hak, kewajiban, 
maupun kehormatan diri sendiri dan ihak lain; Berpegang teguh pada keputusankeputusan yang diambil atas dasar penalaran dan perhitingan yang mantap.

Faktor Sarana atau Fasilitas, tanpa adanya sarana atau fasilitas tertentu, maka tidak mungkin penegakan hukum akan berjalan dengan lancar. Sarana atau fasilitas tersebut antara lain, mencakup tenaga manusia yang berpendidikan dan trampil, organisasi yang baik, peralatan yang memadai, keuangan yang cukup, dan seterusnya.

Sarana atau fasilitas mempunyai peran yang sangat penting dalam penegakan hukum. Tanpa adanya sarana atau fasilitas tersebut, tidak akan mungkin penegak hukum menyerasikan peranan yang seharusnya dengan peranan yang aktual. Khususnya untuk sarana atau fasilitas tesebut, sebaiknya dianut jalan pikiran, sebagai berikut: Yang tidak ada-diadakan yang baru betul; Yang rusak atau salah-diperbaiki atau dibetulkan; Yang kurang-ditambah; Yang macet-dilancarkan; Yang mundur atau merosot-dimajukan atau ditingkatkan; Faktor Masyarakat.

Penegakan hukum berasal dari masyarakat, dan bertujuan untuk mencapai kedamaian dalam masyarakat. Oleh karena itu, dipandang dari sudut tertentu, maka masyarakat dapat mempengaruhi penegakan hukum tersebut.

Masyarakat Indonesia mempunyai kecendrungan yang besar untuk mengartikan hukum dan bahkan mengidentifikasikannya dengan petugas (dalam hal ini penegak hukum sebagai pribadi). Salah satu akibatnya adalah, bahwa baik buruknya hukum senantiasa dikaitkan dengan pola prilaku penegak hukum tersebut.

Faktor Kebudayaan, kebudayaan (system) hukum pada dasarnya mencakup nilainilai yang mendasari hukum yang berlaku, nilai-nilai yang merupakan konsepsi abstrak mengenai apa yang dianggap baik (sehingga dianuti) dan apa yang dianggap buruk (sehingga dihindari). Pasangan nilai yang berperan dalam hukum, adalah sebagai berikut : Nilai ketertiban dan nilai ketentraman; Nilai jasmani/kebendaan dan nilai rohani/keakhlakan; Nilai kelanggengan/konservatisme dan nilai kebaruan/inovatisme.

Menyadari tingginya tingkat kejahatan, maka secara langsung atau tidak langsung mendorong pula perkembangan dari pemberian reaksi terhadap kejahatan dan pelaku kejahatan pada hakikatnya berkaitan dengan maksud dan tujuan dari usaha penanggulangan kejahatan tersebut.

Menurut Hoefnagels upaya penanggulangan kejahatan dapat ditempuh dengan cara: a). Criminal application : (penerapan hukum pidana). contohnya : penerapan Pasal 354 KUHP dengan hukuman maksimal yaitu 8 tahun baik dalam tuntutan maupun putusannya. b). Preventif without punishment : (pencegahan tanpa pidana), contohnya : dengan menerapkan hukuman maksimal pada pelaku kejahatan, maka secara tidak langsung memberikan prevensi (pencegahan) kepada publik walaupun ia tidak dikenai hukuman atau shock therapy kepada masyarakat. c). Influencing views of society on crime and punishment (mas media mempengaruhi pandangan masyarakat mengenai kejahatan dan pemidanaan lewat mas media), contohnya : mensosialisasikan suatu undang-undang dengan memberikan gambaran tentang bagaimana delik itu dan ancaman hukumannya.

Upaya pencegahan kejahatan dapat berarti menciptakan suatu kondisi tertentu agar tidak terjadi kejahatan. Kaiser memberikan batasan tentang pencegahan kejahatan sebagai suatu usaha yang meliputi segala tindakan yang mempunyai tujuan yang khusus 
untuk memperkecil ruang segala tindakan yang mempunyai tujuan yang khusus untuk memperkecil ruang lingkup kekerasan dari suatu pelanggaran baik melalui pengurangan ataupun melalui usaha-usaha pemberian pengaruh kepada orang-orang yang potensial dapat menjadi pelanggar serta kepada masyarakat umum.

Peran pemerintah yang begitu luas, maka kunci dan strategis dalam menanggulangi kejahatan meliputi ketimpangan sosial, diskriminasi nasional, standar hidup yang rendah, pengangguran dan kebodohan di antara golongan besar penduduk. Bahwa upaya penghapusan sebab dari kondisi menimbulkan kejahatan harus merupakan strategi pencegahan kejahatan yang mendasar.

Secara sempit lembaga yang bertanggung jawab atas usaha pencegahan kejahatan adalah polisi. Namun karena terbatasnya sarana dan prasarana yang dimiliki oleh polisi telah mengakibatkan tidak efektifnya tugas mereka. Lebih jauh polisi juga tidak memungkinkan mencapai tahap ideal pemerintah, sarana dan prasarana yang berkaitan dengan usaha pencegahan kejahatan. Oleh karena itu, peran serta masyarakat dalam kegiatan pencegahan kejahatan menjadi hal yang sangat diharapkan.

Kejahatan merupakan gejala sosial yang senantiasa dihadapi oleh setiap masyarakat di dunia ini. Kejahatan dalam keberadaannya dirasakan sangat meresahkan, disamping itu juga mengganggu ketertiban dan ketentraman dalam masyarakat berupaya semaksimal mungkin untuk menanggulangi kejahatan tersebut.

Upaya penanggulangan kejahatan telah dan terus dilakukan oleh pemerintah maupun masyarakat. Berbagai program dan kegiatan telah dilakukan sambil terus menerus mecari cara paling tepat dan efektif untuk mengatasi masalah tersebut.

\section{SIMPULAN}

Unsur-unsur tindak pidana penggelapan terdiri dari unsur Subyektif Delik berupa kesengajaan pelaku untuk menggelapkan barang milik orang lain yang dirumuskan dalam pasal undang-undang melalui kata: dengan sengaja dan unsur Oyektif Delik yang terdiri atas: unsur barang siapa, unsur menguasai secara melawan hukum, unsur suatu benda, unsur sebagian atau seluruhnya milik orang lain dan unsur benda tersebut ada padanya bukan karena kejahatan. Pertanggungjawaban pelaku tindak pidana penggelapan dalam wilayah Pengadilan Negeri Lubuk Pakam adalah meliputi adanya unsur kesengajaan (dolus) atau kelalaian (culpa) yang dilakukan seorang pelaku penggelapan, tidak adanya alasan peniadaan pidana terhadap perbuatan pelaku penggelapan, serta perbuatan penggelapan tersebut adalah perbuatan yang melawan hukum sebagaimana diatur dalam KUH Pidana. Kendala dalam penegakan hukum terhadap tindak pidana penggelapan di wilayah Pengadilan Negeri Lubuk Pakam adalah pola dan bentuk serta modus operandi kejahatan penggelapan semakin berkembang, perkembangan teknologi yang semakin maju serta sulitnya mencari alat bukti. Upaya penegakan hukum terhadap tindak pidana penggelapan di wilayah Pengadilan Negeri Lubuk Pakam dengan cara menempatkan pegawai yang bertugas dalam pengelolaan keuangan sebanyak dua orang. Dengan adanya pegawai yang dua orang tersebut maka salah satu pegawai akan bertanggungjawab kepada pegawai lainnya serta dengan cara meningkatkan kesejahteraan pegawainya. 
Pegawai juga oleh perusahaan harus diperhatikan oleh perusahaan kesejahteraannya sehingga pegawai tidak memiliki niat untuk melakukan penggelapan.

\section{DAFTAR PUSTAKA}

Alwi, H, (2006) Kamus Besar Bahasa Indonesia, Jakarta: Balai Pustaka,.

Andi Hamzah (ed.), 2003, Bunga Rampai Hukum Pidana dan Acara Pidana, Jakarta: Ghalia Indonesia, 1986. Departemen Pendidikan Nasional. (2003), Kamus Besar Bahasa Indonesia. (Jakarta: PN. Balai Pustaka, Hadikusuma, H. (1992). , Bahasa Hukum Indonesia, Bandung: Alumni,

Hakim, A., dan Tan K., (2013), Peranan Polri dalam Penanggulangan Tindak Pidana Pencurian oleh Anak (Studi di Wilayah Hukum Kepolisian Resort Kota Medan), Mercatoria, 6 (2)

Kaelan M.S, (2005). Metode Penelitian Kualitatif Bidang Filsafat (Paradigma bagi Pengembangan Penelitian Interdisipliner Bidang Filsafat, Budaya, Sosial, Semiotika, Sastra, Hukum dan Seni), Yogyakarta : Paradigma.

Kanter, E.Y. dan SR Sianturi, (2003). Asas-Asas Hukum Pidana di Indonesia, Jakarta: Storia Grafika,.

Kitab Undang-Undang Hukum Pidana (KUHP)

Koentjaraningrat, (1989). Metode-Metode Penelitian Masyarakat, Jakarta: PT. Gramedia,

Moleong, L.J. (2002). Metodologi Penelitian Kualitatif, Bandung, Remaja Rosdakarya.

Muhammad Nurul Huda. "Pengertian Tanggung Jawab (Hukum)". http://criminalist. multiply.com/journal/item/5?\&show_interstitial=1\&u=\%2Fjournal\%2Fitem.

Nasution, E. (2015). PERTANGGUNGJAWABAN PIDANA PELAKU TINDAK PIDANA PENYELUNDUPAN DI INDONESIA. JURNAL MERCATORIA, 8(1), 1-17. doi:https://doi.org/10.31289/mercatoria.v8i1.

Poernomo, B. (2001). Azas-Azas Hukum Pidana. Jakarta: Ghalia Indonesia.

Pound, R. (1982). Pengantar Filsafat Hukum, Diterjemahkan dari edisi yang diperluas oleh Mohammad Radjab, Jakarta: Bhratara Karya Aksara.

Prakoso, D, (1987). Asas-Asas Hukum Pidana di Indonesia, Yogyakarta: Liberty,

Roeslan Saleh, Sifat Melawan Hukum Dari Perbuatan Pidana, Jakarta: Aksara Baru.

Sianturi, S.R. (1996). Asas-Asas Hukum Pidana Indonesia dan Penerapanya, Bandung: Alumni.

Soekant, S. (1986). Faktor-Faktor Yang Mempengaruhi Penegakan Hukum, . Jakarta: Rajawali Pers.

Soekanto, S. (1983). Penegakan Hukum, Jakarta : Bina Cipta.

Soekanto, S. (2004). Pengantar Penelitian Hukum. Jakarta: Universitas Indonesia Press.

Soekanto, S. dan Sri Mamudji, (1995). Penelitian Hukum Normatif Suatu Tinjauan Singkat, Jakarta: Raja Grafindo Persada.

Soesilo, R. (1991). Kitab Undang-Undang Hukum Pidana (KUHP) Serta Komentar-Komentarnya Lengkap Pasal Demi Pasal, Bogor: Politeia.

Soesilo, R. (2001). Kitab Undang-Undang Hukum Pidana (KUHP) Beserta Penjelasannya. Bogor: Politeia.

Sunggono, B. (1997). Metodologi Penelitian Hukum. Jakarta: Raja Grafindo Persada.

Undang-Undang Nomor 8 Tahun 1981 Tentang Hukum Acara Pidana (KUHAP)

Wikipedia Indonesia. "Kendaraan Bermotor", Melalui https://id.wikipedia.org/wiki/ Kendaraan_bermotor. Wiyanto, R. (1987). Asas-Asas Hukum Pidana Indonesia. Bandung: Mandar Maju,

Zebua, F.R.P., Iman J., dan Taufik S., (2008), Tanggungjawab Pelaku Tindak Pidana Korupsi dan Ahli Warisnya Dalam Pembayaran Uang Pengganti Kerugian Keuangan Negara Ditinjau Dari Aspek Hukum Perdata (Studi Kasus Pada Pengadilan Negeri Medan), Mercatoria, 